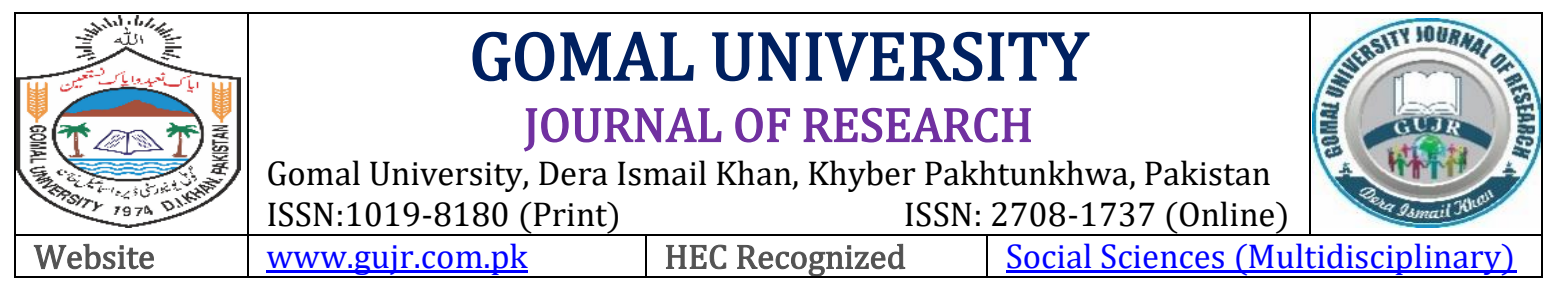

\title{
THE EFFECTS OF STRUCTURAL CAPITAL ON ORGANISATIONAL EFFICIENCY
}

\author{
Friday Ogbu Edeh ${ }^{1}$, Yeo Sook Fern ${ }^{2}$, Abid Hussain Nawaz ${ }^{3}$ \\ ${ }^{1}$ Department of Business Administration, Alex Ekwueme Federal University, Ndufu-Alike, NIGERIA \\ ${ }^{2}$ Faculty of Business, Department of Business Administration, Multimedia University, MALAYSIA \\ ${ }^{3}$ Director, High Aims School Systems, Jahan Khan Bhakkar, PAKISTAN
}

\begin{tabular}{|c|c|}
\hline ARTICLE INFO & ABSTRACT \\
\hline $\begin{array}{l}\text { Keywords: } \\
\text { Structural Capital, } \\
\text { Organisational } \\
\text { Efficiency, Process } \\
\text { Capital, Customer } \\
\text { Capital, Innovation } \\
\text { Capital } \\
\text { Article History: } \\
\text { Date of Submission: } \\
\text { 26-09-2020 } \\
\text { Date of Acceptance: } \\
\text { 15-03-2021 } \\
\text { Date of Publication: } \\
\text { 31-03-2021 }\end{array}$ & 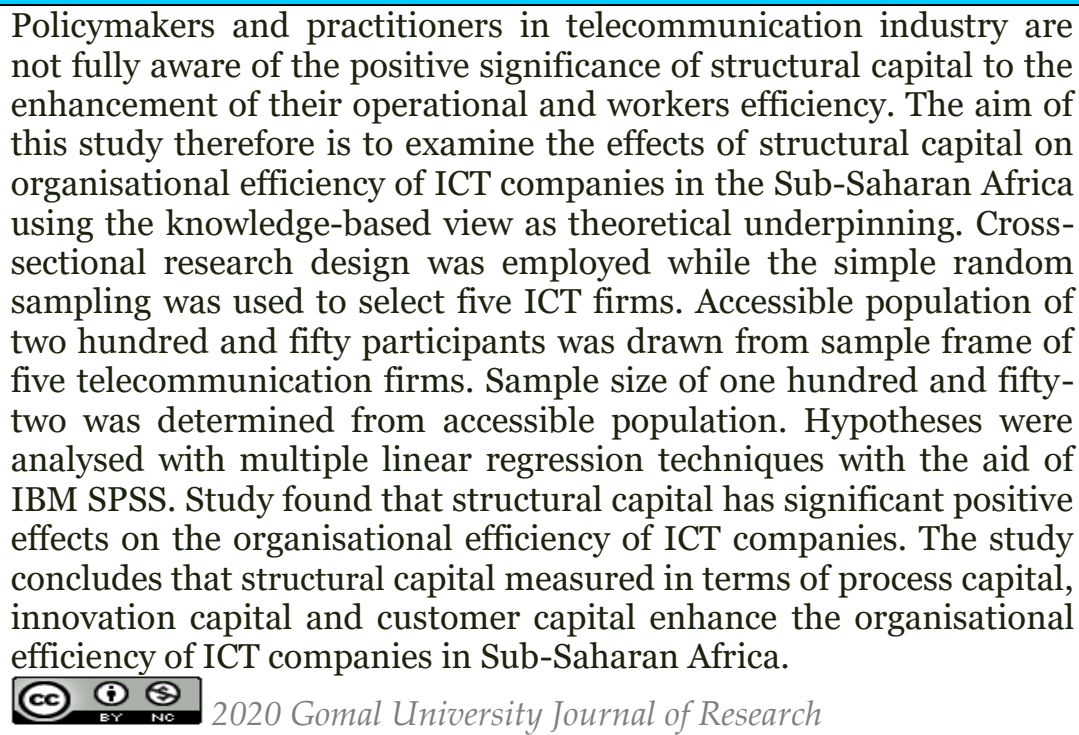 \\
\hline Corresponding Author & Friday Ogbu Edeh: edeh.ogbu@gmail.com \\
\hline$\overline{\mathrm{DOI}}$ & https://doi.org/10.51380/gujr-37-01-01 \\
\hline
\end{tabular}

\section{INTRODUCTION}

The information and communication technology industry in Nigeria has been very competitive since the Federal government liberalised it in 2001. Thus, for the information and communication technology companies in Nigeria to survive in this era of the digital colonisation and knowledge economy, they must be resilient. Another way to attain this is for information and communication technology companies to develop its structural capital rather than dwelling on traditional human capital that will soon be replaced by artificial intelligentsias. This is reason why Nonaka, Krogh \& Voelpel (2006) contended that in knowledge economy, organisational efficiency would no longer be ascertained by employee performance rather; it will be determined by structural capital that supports their operations. Thus, knowledge-based theory of the firm supports structural capital of the organisation and its criterion outcomes (Pendo, 2020). However, this theory is fully discussed 
on theoretical underpinning section of study. Meanwhile, Mouzas (2006) assert that organisational efficiency increases performance, leadership competencies and eliminates financial and material leaks within internal and external hemispheres. In furtherance, information and communication technology companies in Nigeria falls within knowledge-based companies that harvest both implicit and the explicit knowledge of its human resource to achieve its objectives through their structural capital.

This is the rationale for this study since Van-Zyl (2005) opined that structural capital is owned by a firm which is quite different from human capital that is never owned by any organisation. From the preceding, Waseem \& Loo-See (2018) stressed that structural capital serves as a baseline for employees' to be inventive in the organisation as compared with human capital despite belonging totally to the organisations. The structural capital also offers an enabling work environment for the innovative organisational learning, knowledge growth and codification of the information to knowledge leading to highly productive firm performance (Salim \& Djausin, 2020; Waseem \& Loo-See, 2018). Al-hawajreh (2013) stressed that structural capital is a function of process capital, customer capital, innovation capital and corporate culture that distinguishes one firm from the another and gives them the competitive advantage. Nevertheless, definitive function of structural capital is to enable the employees and their managers' leverage on the human capital as well as ensure that efficiency is achieved and sustained. Structural capital enhances the capabilities and efficiency of the networked organisations, especially as it concerns their performance (Muchran, 2020; Plessis, 2007). Moczydlowska (2007) added that the application of the structural capital promotes information and communication technology firms to sustain dominance in product life cycle.

The indicators of structural capital comprise of customer capital; innovation capital, and process capital (Mosavi, Nekoueizadeh \& Ghaedi, 2012; Van-Zyl, 2005). Al-hawajreh (2013) asserted that structural capital of organisations enables them to withstand environmental turbulences anytime. Yasmin (2016) added that firm innovations could only be successful when its structural capital is developed. However, previous trends of studies (Abdirahman \& Tarique, 2020; Kinda \& Maher, 2016; Fernández, Costa \& Dorrego, 2014; Al-hawajreh, 2013; Najihah, Malina \& Rosfatihah, 2011) had investigated structural capital using different criterion constructs in other industries and countries but most of them were unable to address how structural capital will enhance efficiency of information and communication technology firms in Sub-Saharan Africa work environment. Based on this research gap, the researchers were motivated to investigate the effects of structural capital on organisational efficiency of information and communication technology companies in Sub-Saharan Africa using Nigeria as a geographical scope. Drawing from the above, some of the problems facing Nigerian information and communication technology companies started when it was thus deregulated in 2001. On the consumer angle, the commission listed some problem facing them as; underprivileged data services and billings, poor management of complaints resolution, qualities of the services and misinformation concerning the location of the base stations (Njoku, 2017).

Most of information and communication technology companies in Nigeria have also faced many problems since they commenced operation in Nigeria. The Nigerian Communication Commission (2012) cited in Mojekwu (2012) highlighted some of these challenges as lack of infrastructure, inadequate power supply, insecurity, multiple regulations and multiple taxations; vandalization of telecom equipment; delay in securing approval for the sites for new base stations; harassment by some government groups especially at the state level and right of way approvals. However, apart from above problems, most ICT companies in Nigeria are facing severe challenges of inadequate structural capital to enhance the quality service delivery that will lead to organisational efficiency. 
Lack of adequate structural capital to handle knowledge accumulated by companies in the form of software and databases, information resources, technologies, organisational processes, intellectual property rights, procedures, databases, customer files, manuals, and trademarks have also been a major problem facing the telecommunication industry in Nigeria. To resolve the above maladies, structural capital components which are process capital, innovation capital and customer capital must utilise so as to enhance organisational efficiency of ICT companies operating in Sub-Saharan Africa.

\section{Objectives of Study}

The aim of this study is to investigate the effects of structural capital on organisational efficiency of information and communication companies in the Sub-Saharan Africa, Nigeria. Exactly, study sought to:

1. Examine the effects of the process capital on operational efficiency of the ICT companies

2. Investigate the effects of innovation capital on technological efficiency of ICT companies

3. Ascertain the effects of customer capital on the workforce efficiency of the ICT companies

\section{LITERATURE REVIEW}

The existing literature about the topic/variables has been presented in this section from where the hypotheses have been extracted based upon the relationship among the research variables under considerations.

\section{Structural Capital}

Structural capital had been explored by human resource management scholars (Armstrong, 2010; Fiala \& Borůvková, 2012). Structural capital is embedded in intellectual capital which consists of the knowledge, customer relationships, workplace technology, employee experience and creativity (Edvinsson \& Malone, 1997; Mayo, 2001). Structural capital remains the pool of knowledge that is left in databases of a firm at the close of work (Luminita, Dan \& Anca, 2015; Malhotra, 2003; VanCaenegem, 2002; Mouritsen, Ulf, Hanno, Stolowy, Rita, Leandro \& Paloma, 2001; Edvinsson \& Malone, 2001). The structural capital is a combination of strategies, systems and procedures put in place by organisations to deliver quality services to customers (Grantham, 2002; Kong, 2008; Jansen, Tempelaar, Bosch \& Volberda, 2009). Structural capital covers of applied technological tools that supports human capital (Bontis, Keow \& Richardson, 2000; Watson \& Stanworth, 2006). The structural capital is a subset of organisational capital (Eisfeldt \&Dimitris, 2013). The components of structural capital include innovation capital, customer capital and process capital (Mosavi, Nekoueizadeh \& Ghaedi, 2012; Van-Zyl, 2005). These indicators have been found to have predicted organisational performance, effectiveness, efficiency and sustainability by human resource management scholars (Dessler, 2020; Byars \& Rue, 2010; Mahapatro, 2010; Biswajeet, 2010).

It is based on evidence that researchers adopted process capital, customer capital and innovation as dimensions of structural capital in this study. Nevertheless, the structural capital consists of patents rights and licenses that assist firms to operate efficiently and competitively in the global market (Yongfu, Yu, Jinxin \& Chengwei, 2019; Swart, 2006; Spacey, 2017). It has been shown that structural capital also consists of non-human knowledge in the organisation coupled with the databases, strategies, processes, organisational charts and routines (Muchran, 2020; Abdollah, 2014; Bontis, Chua \& Richardson, 2000; Luminita, Dan \& Anca, 2015; Wang \& Lu, 2017). The structural capital simply put is intangible knowledge (Luminita, Dan \& Anca, 2015; Kuo \& Yang, 2012; Fiala \& Borůvková, 2012). Thus, relationship between telecommunication companies and its customers can be attributed to its structural capital. It is found that structural capital and 
innovation capital are positively correlated with enterprise performance (Abdirahman \& Tarique, 2020).

\section{Structural Capital Components}

The components or dimensions of the structural capital are process capital, innovation capital and customer capital (Muchran, 2020; Vom-Brocke \& Rosemann, 2010; Bontis, Keow \& Richardson, 2000; Abdollah, 2014). Process capital involves techniques, programmes and processes utilised by firms to implement effective delivery of goods and services to potential consumers (Abdollah, 2014). Process capital when created can be enhanced with business process mapping and business process management (Jacka \& Paulette, 2011; Vom-Brocke \& Rosemann, 2010). The organisations invest in process capital to fabricate strong infrastructure that will assist them in achieving their goals. Given the changes in industry and technology, process capital development evolves and the interacts with environmental changes (Shang \& Lin, 2010). The examples of strong process capital include information technology. Thus, in line with the above evidence, first hypothesis is hereby formulated.

HA1: Process capital has a positive significant effect on operational efficiency

Innovation capital is made up of firms' intellectual property (Abdollah, 2014). This is a category of structural capital that includes digital applications that helps organisation to innovate beyond employees' skills (Yongfu et al., 2019). In other words, where innovation is used for creative ability of employees, computer mechanisms would be deployed to hasten work operations (Spacey, 2017; Abdollah, 2014; Edvinsson \& Malone, 1997). It is against this premise that second hypothesis is formulated.

HA2: Innovation capital has a positive significant effect on technological efficiency

Customer capital refers to relationship that exists between firms' and customers, suppliers and other stakeholders (Bontis, Keow \& Richardson, 2000). Customer capital link organisations with the external environment as well as obtain information about customer's need (Waseem \& LooSee, 2018). Customer capital is formed out of relationships with customers (Guna \& Natalja, 2008). In this connection, the customer capital comprises of the human relations or the customer relationship management skills. Firms and customer relationship is the significant asset, and through the operation and management of this asset, competitive advantage is sustained (Bontis, Keow \& Richardson, 2000). From the above argument and evidence, the third hypothesis is then hypothesised.

HA3: Customer capital has a positive significant effect on workforce efficiency

\section{Organisational Efficiency}

The organisational efficiency was drawn from managerial efficiency which is the extent to which an organization attains its goals at a lower cost (Robbins \& Judge, 2018). For Jones and George (2017) efficiency is a measure of how well organisational resources are used to achieve a goal. In this study, organisational efficiency refers to how the functional areas of management make use of resources allocated to them judiciously to achieve respective goals. Indicators of the organisational efficiency that are associated with information and communication industry include operational efficiency, technological efficiency and workforce efficiency (Vangie, 2018; McShane \& Glinow, 2018; Robbins \& Judge, 2018; Colquitt et al., 2017). It is based on above evidence that this study adopted operational, technology and workforce efficiency as measures of organisational efficiency. Operational efficiency in this study refers to how well technological-based firms use their webbased digital platforms such as the short messages services (SMS), personal customer services to 
render the quality services to its customers across their networks (Kazmi, 2008). The operational efficiency is concerned with how the organisation communicates its products and services to their customers in a cost-effective manner (Vangie, 2018). Operational efficiency can be achieved when organisations follow their customers to ascertain if they were satisfied (MYABCM, 2016; Martin, 2007).

The technological efficiency refers to how productive an information and communication firm can utilise fewest inputs, or resources, necessary to do job (Mack, 2018). The technological efficiency is better with knowledge, training, automation and ICT tools for workers in the communication industry (McShane \& Glinow, 2018; Spacey, 2017). The technological efficiency is how well ICT companies utilises its resources judiciously to achieve their predetermined goals. Technological efficiency looks at how well organisation utilises all of its resources like labour, capital, materials and people to produce its outputs (McShane \& Glinow, 2018). For example, firms that use the database for customer automation can reduce number of employees handling the task (Colquitt et al., 2017; Jones \& George, 2006). The workforce efficiency is concerned with workers capacity to reduce or minimise costs of service delivery to customers within their respective departments e.g., minimisation of transporting goods to sole distributors. It has been established that workers are the people that determine the performance and profitability of organisation (Wang \& Lu, 2017). In which case, the rate at which the workers submit expenditures for their departments to the management will determine the survivability of the organisation. In ICT companies, production section makes the accessories readily available for the marketing department who then sales the gadgets to the esteemed consumers. On the other hand, the accounting or the finance department makes the capital available for the purchase of all the materials needed to produce the desired ICT gadgets.

Figure 1 Conceptual Framework

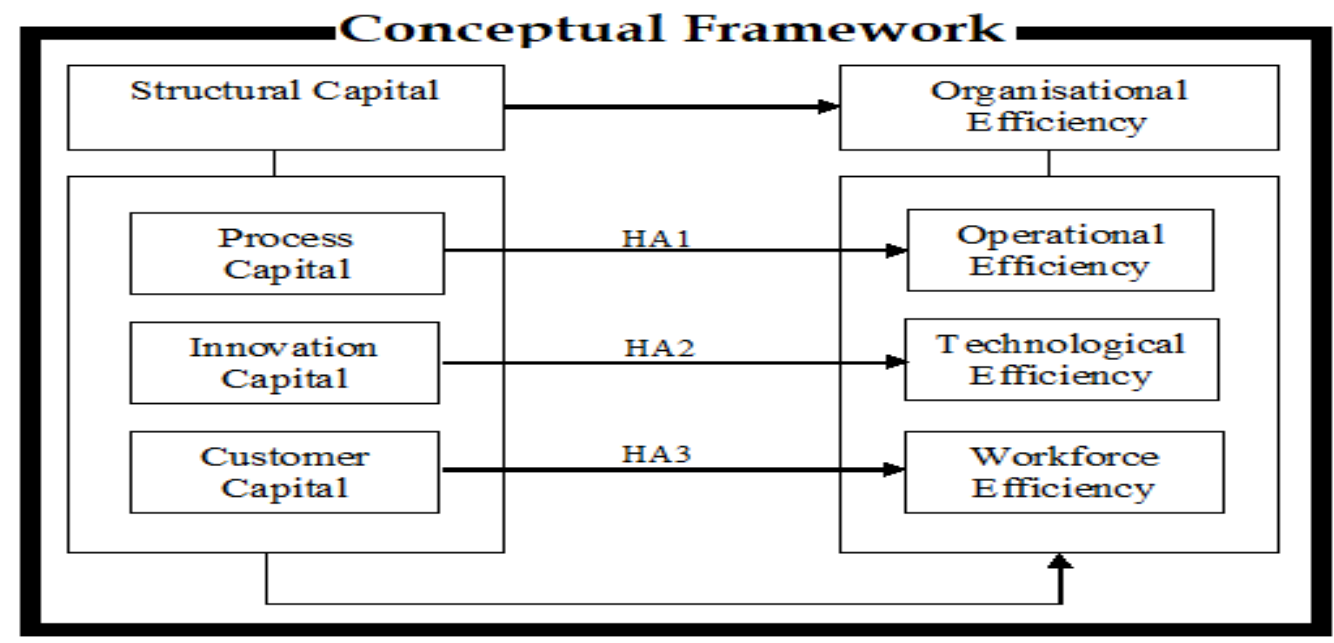

Source: Researcher's Framework

\section{Theoretical Framework}

The underpinning theory of this study is knowledge-based theory of firm propounded by Spender (1996) and adopted by Pendo (2020). This theory holds that the knowledge is the most strategic competitive and significant intangible resources of the firm which distinguishes one organisation from another (Li et al., 2020). Knowledge based theory holds view that since intangible resources 
are not easy to imitate due to its complex nature; heterogeneous knowledge base and capabilities among firms are determinant of sustained competitive edge and superior corporate performance (Alavi \& Leidner 2001). This intangibility is embedded and carried over structural capital of the organisation driven by process capital, customer capital and innovation capital which promotes efficiency measured in terms of the operational efficiency, technological efficiency and workforce efficiency.

\section{METHODOLOGY}

The methods and procedures used for conducting this study has been presented in this section. These tools and techniques are thus vital for chasing the desired objectives of study to reach the conclusion.

\section{Research Design}

Research design employed in this study is cross-sectional survey. Cross sectional design is type of study that researchers' sample and data collected at a single moment in time (Sekaran \& Bougie, 2016).

\section{Participants and Sampling Procedure}

The simple random sampling was used to select five ICT companies from a sample frame of five telecommunication companies registered with Enugu State Ministry of Science and Technology. Accessible population of two hundred and fifty participants (middle line managers, Head of HRM and supervisors) were drawn from the five telecommunication companies. The sample size of 152 was determined from the population with Krejcie and Morgan (1970) sample size determination formula.

\section{Data Collection}

Self-design close-ended questionnaire was used to collect responses from participants on the effect of structural capital on organisational efficiency of ICT companies. Thus, 152 questionnaires were self-administered, but only one hundred and forty-eight (148) were returned and found valid for analysis.

\section{Validity and Reliability of Instrument}

The face and content validation were used to determine the instrument validity. Based on this, the instrument was issued to experts in the management and psychology disciplines, and it was discovered that it was valid. Cronbach $\alpha$ was used to determine the reliability of the instrument. The study adopted Nunnally (1978) recommendation of 0.7 trench hold of reliability as seen on table 1.

\section{Measurement of Variables}

The validated Structural Capital Questionnaire (SCQ) comprising of 9-items by Liu (2017) and evidenced in Li et al. (2020) was adopted and Organisational Efficiency Questionnaire containing 9-items by Edeh et al., (2020) was adopted and modified in line with current study environment. The variables were scaled on the 5 -point Likert scales which ranges from $5=$ VGE to $1=$ Very Low Extent.

\section{Method of Data Analysis}

The participants demographic profiles were analysed with the frequency distribution while three hypotheses of study were analysed with the multiple linear regression with the package of SPSS 20.0. 


\section{DATA ANALYSIS}

The data has been analyzed in this section which provides statistical evidence about description as well as relationships among the research variables under considerations to reach conclusion of the study.

\section{Table 1}

Reliability Statistics

\begin{tabular}{lcc}
\multicolumn{1}{c}{ Variable } & Cronbach's $\alpha$ & N of Items \\
\hline Process capital & .77 & 3 \\
Customer capital & .76 & 3 \\
Innovation capital & .72 & 3 \\
Technological efficiency & .78 & 3 \\
Workforce efficiency & .74 & 3 \\
\hline Operational efficiency & .71 & 3 \\
\hline
\end{tabular}

Table 2

Demographic Profiles of Participants

\begin{tabular}{|c|c|c|}
\hline Demographics & Frequency & Percentage (\%) \\
\hline \multicolumn{3}{|l|}{ Gender } \\
\hline Male & 92 & 62.2 \\
\hline Female & 56 & 37.8 \\
\hline \multicolumn{3}{|l|}{ Age Bracket } \\
\hline 41 years \& above & 51 & 34.5 \\
\hline $31-40$ years & 71 & 48.0 \\
\hline $18-30$ years & 26 & 17.6 \\
\hline \multicolumn{3}{|l|}{ Education } \\
\hline PhD degree & 6 & 4.1 \\
\hline Master degree & 17 & 11.5 \\
\hline Diploma & 32 & 21.6 \\
\hline Bachelor degree & 93 & 62.8 \\
\hline
\end{tabular}

Source: Field survey (2020)

\section{Table 3}

Multiple Linear Regression Results

\begin{tabular}{llll}
\hline Structural Capital & & Organizational Efficiency \\
& Operational & Technological & Workforce \\
Process capital & $.000 \& .701^{*}$ & Efficiency & Efficiency \\
Innovation capital & - & - & - \\
Customer capital & - & $.000 \& .708^{*}$ & - \\
R & $.701 \mathrm{a}$ & - & $.000 \& .743^{*}$ \\
R2 & .491 & $.708 \mathrm{a}$ & $.743 \mathrm{a}$ \\
Adjusted R2 & .488 & .501 & .552 \\
F value & $140.877^{* *}$ & .498 & .549 \\
df. & 3.91 & $146.720^{* *}$ & $179.843^{* *}$ \\
Coefficient & .670 & 3.91 & 3.91 \\
Std. Error & .056 & .657 & .697 \\
\hline t-statistics & 11.869 & .054 & .052 \\
\hline N & & 12.113 & 13.411
\end{tabular}

$\mathrm{N}=148, \mathrm{p}<0.05$ 
Overall regression results of models revealed high correlation of $.701, .708$ and .743 respectively, which are reasonable. R2 of the models shows that $49.1 \% ; 50.1 \%$ and $55.2 \%$ of the total variation in organisational efficiency can be explained by structural capital. Again, difference between R2 and adjusted R2 are less than 5\% which means that there is no sample error (George \& Mallery, 2016). The goodness of fit of model is endorsed significant as F-statistics $\left(140.877^{* *} ; 146.720^{* *}\right.$; $\left.179.843^{* *}\right)$ are greater than 3.91 degree of freedom $(1,146)$. Therefore, all alternate hypotheses are accepted while null hypotheses were rejected. This is also supported by sig. value of $\mathrm{p}<0.05$, implying that overall regression model is significant at $5 \%$ level of significance (George \& Mallery, 2016).

\section{DISCUSSION}

Based on the result above, the study found that "structural capital" has significant positive effects on organisational efficiency of ICT companies. Specifically, process capital has significant positive impact on operational efficiency; innovation capital has significant positive effect on technological efficiency, and customer capital has a significant positive effect on workforce efficiency. These findings are in line with previous empirical investigations such as Abdirahman \& Tarique (2020); Kinda \& Maher (2016); Fernández, Costa, \& Dorrego (2014); Al-hawajreh (2013); Najihah, Malina \& Rosfatihah (2011). Abdirahman and Tarique (2020) found that the structural capital and the innovation capability has positive significant correlation with enterprise performance in Pakistan. Kinda and Maher (2016) found a significant positive relationship involving the structural capital and innovation performance in Syrian Universities. Fernández, Costa \& dDorrego (2014) found that "structural capital" has significant positive rapport with product innovation performance at the Portuguese small and medium enterprises. Al-hawajreh (2013) found that "structural capital" has a significant positive relationship with the business performance of Jordanian Pharmaceutical Manufacturing Companies. Najihah, Malina and Rosfatihah (2011) found that "structural capital" has significant positive influence on performance of Telekom Malaysia. Albeit, previous findings on structural capital as mentioned above, did not examined predictability of structural capital on efficiency which makes this study outstanding as well as novel in body of the structural capital knowledge.

\section{CONCLUSION}

The conclusion is all about the decision making about the research questions through certain extracted questions in form of hypotheses. The results of study provide significant information in reaching conclusion and making the decisions. In line with the study findings, it was concluded that the structural capital measured in terms of process capital, innovation capital and customer capital enhance organisational efficiency of the ICT companies in the Sub-Saharan Africa which is supported by operational efficiency, technological efficiency and workforce efficiency. Therefore, the results provide significant information to reach the conclusion of the study. The results suggest some implications as extracted from the conclusion of the current study. The implication of the findings of this study is somehow interesting as it offered that managers and professionals of ICT based companies, including the policymakers should utilise their structural capital as the competitive advantage and tool to improve the efficiency of their operations in their respective industries.

\section{REFERENCES}

Abdirahman, M. D., \& Tarique, R. (2020). Impact of structural capital and innovation capability on firm performance, (Case study of Pharma industry in Karachi-Pakistan). The Strategic Journal of Business \& Change Management, 7(1), 736 -748. 
Abdollah, A. D. (2014). The study of the relationship between intellectual capital and performance in Saderat bank of Tehran. International Academic Journal of Business Management, 3(9), 9-17.

Alavi, M., \& Leidner, D.E. (2001). Review: Knowledge management and knowledge management systems. MIS Quarterly, 25(1), 107-136.

Al-hawajreh, K. M. (2013). The impact of structural capital on business performance in Jordanian pharmaceutical manufacturing companies. European Journal of Business and Management, 5(10), 177-189.

Armstrong, M. (2010). A handbook of human resource management practice(10 $\left.{ }^{\text {th }} \mathrm{ed}\right)$. Kogan Page: London.

Biswajeet, P. (2010). The Human Resource Management ( $3^{\text {rd }}$ edition.). New Delhi: PHL Learning Private Limited.

Bontis, N., Chua, W., \& Richardson, S. (2000). Intellectual Capital and the Nature of Business in Malaysia. Journal of Intellectual Capital, 1, 85- 100.

Byars, L. L., \& Rue, L. W. (2010). The Human Resource Management (10 ${ }^{\text {th }}$ edition). New York: McGraw-Hill.

Colquitt, J. A., Lepine, J. A., \& Wesson, M. J. (2017). Organizational Behaviour: Improving performance and commitment in the workplace ( $6^{\text {th }}$ ed.). New York: McGraw-Hill Education.

Dessler, G. (2020). The Human Resource Management (16 $6^{\text {th }}$ edition). United States: Pearson Education, Incorporation.

Edvinsson, L., \& Malone, M. S. (1997). Intellectual capital: realising your company's true value by Hidden Brainpower. New York: Harper business.

Edvinsson, L., \& Malone, M. S. (2001). The Intellectual Capital: The related reviews: Wydaw Naukowe PWN, 149.

Eisfeldt, A., \& Dimitris, P. (2013). Organisation capital and the cross-section of expected returns, Journal of Finance, 68, 1365-1406.

Fernández, C., Costa, R. V., \& Dorrego, P. F. (2014). The impact of structural capital on product innovation performance: An empirical analysis. Int. J. Knowledge-Based Development, $5(1), 63-79$.

Fiala, R., \& Borůvková, J. (2012). The valuation of organizational capital. Journal of Competitiveness, 4(4), 123-132.

George, D., \& Mallery, P. (2016). IBM SPSS Statistics 23 Step by Step: A Simple Guide and Reference (14 ${ }^{\text {th }}$ ed.). New York: Taylor \& Francis.

Grantham, C. E. (2002). Maximising human capital. People Soft, Inc.

Guna, C., \& Natalja, L. (2008). The role of customer capital for SME sustainable development. Proceedings of the Papers - CRM 2008.

Jacka, J. M., \& Paulette, J. K. (2011). Business process mapping: Improving customer satisfaction. USA: John Wiley \& Sons.

Jansen, J. J., Tempelaar, M. P., Bosch, F.A., \& Volberda, H. W. (2009). Structural differentiation and ambidexterity: The mediating role of integration mechanisms. Organization Science, $20,797-811$.

Jones, R. G., \& George, M. J. (2006). The Contemporary Management ( $4^{\text {th }}$ ed.). New York: McGraw-Hill, Irwin.

Kazmi, A. (2008). Strategic Management and Business Policy (3 ${ }^{\text {rd }}$ ed.). New Delhi: The McGrawHill Publishing Company Ltd.

Kinda, A. D., \& Maher, M.M. (2016). The impact of structural capital on the innovation performance in Syrian Universities: A field study in Tishreen University. European Online Journal of Natural and Social Sciences, 5(3), 664-673. 
Kong, E. (2008). The development of strategic management in the non-profit context: intellectual capital in social service non-profit organisations. International Journal of Management Reviews,10(3), 281-99.

Krejcie, R. V., \& Morgan, D. W. (1970). Determining sample size for research activities. Educational and Psychological Measurement, 30, 607-610.

Kuo, M., \& Yang, C. (2012). Does intellectual capital matter? Assessing the profitability and marketability of IC design companies. Quality \& Quantity, 46(6), 1865-1887.

Li, G., Luo, Z., Anwar, M., Lu, Y., Wang, X., \& Liu, X. (2020) Intellectual capital and the efficiency of SMEs in the transition economy China; Do financial resources strengthen the routes? PLOS ONE, 15(7), e0235462.

Liu, C. H. (2017). The relationships among intellectual capital, social capital, and performanceThe moderating role of business ties and environmental uncertainty. Tourism Management, 61, 553-561.

Luminita, M. G., Dan, C. D., \& Anca, D. (2015). Structural capital - A proposed measurement model. 2nd Global Conference on Business, Economics, Management and Tourism, 30-31 October 2014, Prague, Czech Republic. 1139-1146.

Mack, S. (2018). What is technical efficiency? Retrieved from https://smallbusiness.chron.com/technical-efficiency-65019.html.

Mahapatro, B.B. (2010). The Human Resource Management. The India: The New Age International (P) Ltd.

Malhotra, Y. (2003). Measuring knowledge assets of a nation, in "Knowledge systems for development: Research" In United Nations Headquarters (Ed.). Knowledge Management Network, New York.

Martin, J. A. (2007). Ten Tips for increasing operational efficiency. Retrieved from https://www. informationweek.com/10-tips-for-increasing-operational-efficiency/d/d-id/1057885

Mayo, A. (2001). The human value of the enterprise: valuing people as assets: Monitoring, Measuring, Managing. London: Nicholas Brealey Publishing.

McShane, S. L., \& Glinow, M. A. (2018). Organizational behaviour. Emerging knowledge. Global reality ( $8^{\text {th }}$ ed.). New York: McGraw-Hill Education.

Moczydlowska, J. (2007). Organisational knowledge measurement. 6th International Conference on Computer Systems and Industrial Management Application IEEE, 2007.

Mojekwu, E. (2012). Telecom masts \& towers: The Challenges facing the Industry. Retrieved $8 / 6 / 2020$

fromhttps://www.ncc.gov.ng/thecommunicator/index.php?option=com_content\&view=artic le\&id=224:telecom-masts-a-towrs-the-challenges-facing-theindustry\&catid $=25 \& I t e m i d=179$

Mosavi, S. A., Nekoueizadeh, S., \& Ghaedi, M. (2012). A study of relations between intellectual capital components, market value and finance performance. African Journal of Business Management, 6(4), 1396-1403.

Mouritsen, J., Ulf, J, Hanno, R., Stolowy, H., Rita, A., Leandro, C., \& Paloma, S. (2001). Measuring intangibles to understand and improve innovation management (Meritum): European Community under the Targeted Socio-Economic Research Programme (TSER).

Mouzas, S. (2006). Efficiency versus effectiveness in business networks. Journal of Business Research, 59(10-11), 1124-113.

Muchran (2020). Effect of intellectual capital on sustainable financial performance of Indonesian pharmaceutical firms with moderating role knowledge management. Systematic Review Pharmacy, 11 (1), 203-212.

MYABCM (2016, December 06). What is operational efficiency and why is it important? Retrieved from https://www.myabcm.com/blog-post/what-is-operational-efficiency/ 
Najihah, A. R., Malina, H. K., \& Rosfatihah, C. M. (2011). Structural capital and its effect on organisational performance: A case study of Telekom Malaysia Berhad (TM) Headquarters. 2011 IEEE Colloquium on Humanities, Science and Engineering Research (2011), Dec 5-6 2011, Penang, 745-749.

Njoku, L. (2017). NCC identifies core challenges of telecoms subscribers. Retrieved 8/6/2020 from https://guardian.ng/news/ncc-identifies-core-challenges-of-telecoms-subscribers/.

Nonaka, I., Krogh, G., \& Voelpel, S. (2006). Organisational knowledge creation theory: Evolutionary paths and future advances. Organisation Studies, 27(8), 1179-1208.

Nunnally, J. C. (1978). Psychometric theory (2 ${ }^{\text {nd }}$ ed.). New York: McGraw-Hill.

Pendo, S. K. (2020). Does investing in intellectual capital improve financial performance? Panel evidence from firms listed in Tanzania DSE. Cogent Economics \& Finance, 8(1), 1-26.

Plessis, M. (2007). The role of knowledge management in innovation. Journal of Knowledge Management, 11(49), 20-29.

Robbins, S. P., \& Judge, T. A. (2018). Essentials of organizational behavior. Global Edition. England: Pearson Education Limited.

Salim, M. N., \& Djausin, R. P. I. (2020). Determinants of financial performance and its impact on the growth of Islamic bank assets on Indonesia. International Journal of Business, Economics and Management, 7(1), 27-41.

Sekaran, U., \& Bougie, R. (2016). Research methods for business: A skill-building approach (7 ${ }^{\text {th }}$ ed.). United Kingdom: John Wiley \& Sons Ltd.

Shang, S., \& Lin, S. F. (2010). Barriers to implementing ITIL - A multi-case study on the servicebased industry. Contemporary Management Research, 6, 56-70.

Spacey, J. (2017). 7 Examples of organisational capital. Retrieved from https://simplicable. com/new/ organizational-capital.

Spender, J. C. (1996). Making knowledge the basis of a dynamic theory of the firm. Strategic Management Journal, 17, 45-62.

Swart, J. (2006). Intellectual capital: disentangling an enigmatic concept. Journal of Intellectual Capital, Emerald Group Publishing Limited, 7(2),136-159.

Van-Caenegem, W. (2002). Intellectual property and intellectual capital - in Law Papers.Vangie, B. (2018). Operational efficiency. Retrieved from https://www.webopedia.com/TERM/O/ operational efficiency.html

Van-Zyl, C. R. (2005). Structural capital management creates sustainable competitiveness and prolonged first mover advantage. Acta Commercii, 84-95.

Vom-Brocke, J. H., \& Rosemann, M. (2010). Handbook onbusiness process management: Strategic alignment, governance, people and culture (International Handbooks on Information Systems) (Vol. 1). Berlin: Springer

Wang, M. S., \& Lu, S. T. (2017). Can organisation capital improve corporate performance through direct path or mediating effect surveillance of board function: Evidence from Taiwan? Technological and Economic Development of Economy,23(2), 339-374.

Waseem, B., \& Loo-See, B. (2018). Influence of intellectual capital dimensions on knowledge process capability and organisational performance. Asian Journal of Scientific Research, 11 (3), 308-318.

Watson, A., \& Stanworth, J. (2006). Franchising and intellectual capital: A franchisee's perspective. Entrepreneurship Management, 2(3), 337-49.

Yasmin, K. K. (2016). Impact of structural capital on innovation in Australian SMEs. The European Proceedings of Behavioural Sciences, $3^{\text {rd }}$ International Conference on Business and Economics, 21 - 23 September, 2016. 302-312.

Yongfu, L., Yu, S., Jinxin, W., \& Chengwei, L. (2019). Intellectual capital, knowledge sharing, and innovation performance: Evidence from the Chinese Construction Industry. Sustainability, 11(2713), 1-20. 